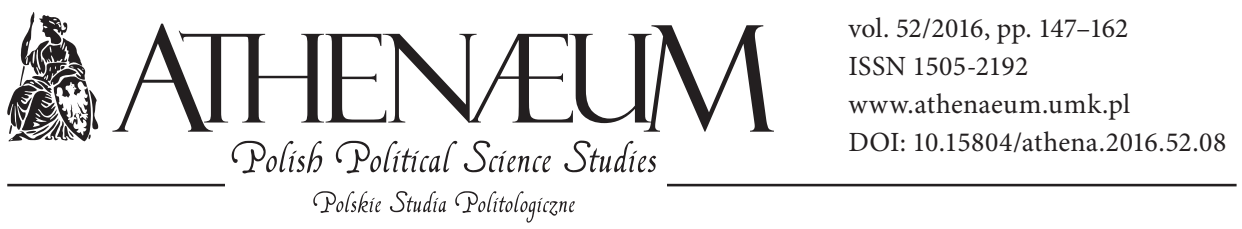

\title{
COALITIONS BETWEEN POLITICAL GROUPS IN THE EUROPEAN PARLIAMENT: AN ANALYSIS OF THE EXPERIENCES OF THE EP OF THE SEVENTH TERM
}

\author{
KOALICJE MIĘDZY GRUPAMI POLITYCZNYMI W PARLAMENCIE \\ EUROPEJSKIM. \\ ANALIZA DOŚWIADCZEŃ PE SIÓDMEJ KADENCJI
}

Agnieszka Nitszke*

\begin{abstract}
- ABSTRACT
The article presents the problem of the functioning of factions within the European Parliament and the formation of coalitions between individual political groups basing on the Rules of Procedure and data from the seventh term of the EP. The article involves an analysis of the principles for forming factions as specified in the Rules of Procedure of the EP and the consequences for the cooperation of national parties in the Parliament arising from these regulations. In the second part of the article, matters concerning coalition formation between political groups within the EP are discussed together with the phenomenon of 'grand coalitions', related definitional problems and the functioning of the entire political system of the EU in this context.
\end{abstract}

Keywords: European Parliament, coalitions, great coalition, political groups (factions) in the European Parliament, European Union
Artykuł przedstawia problem funkcjonowania frakcji w Parlamencie Europejskim i tworzenia koalicji między poszczególnymi grupami politycznymi na podstawie Regulaminu i danych z siódmej kadencji PE. W artykule analizie zostały poddane zasady tworzenia frakcji określone w Regulaminie PE oraz wynikające $\mathrm{z}$ tych przepisów konsekwencje dla współpracy partii narodowych na forum Parlamentu. W drugiej części artykułu przedstawione zostały kwestie związane z tworzeniem koalicji między grupami politycznymi w PE, fenomen "wielkich koalicji” oraz problemy definicyjne związane zarówno z tym zagadnieniem, jak i funkcjonowaniem całego systemu politycznego UE w tym kontekście.

Słowa kluczowe: Parlament Europejski, koalicje, wielka koalicja, grupy polityczne (frakcje) w PE, Unia Europejska

* Jagiellonian University, Institute of Political Science and International Relations. 


\section{INTRODUCTION}

In the formal-legal aspect, the European Union remains an international organisation with certain transnational traits, however, one can still indicate some of its quasi national traits. Most of the hundreds of currently operating international organisations have bodies of parliamentary character, yet those in which deputies exercise direct mandate are rare.

Contemporary democracy operates on the basis of political parties that are seedbeds for political elites and a source of programmes for the ruling party. As early as from the $19^{\text {th }}$ century, political parties have been undertaking the labour of international cooperation, thus giving birth to the currently operating international organisations for political parties. Following World War Two, regional cooperation proved more effective, allowing political parties to exchange their experiences regarding solving problems of similar nature. The emerging European integration marked the beginning of a close collaboration of political parties, first in the Common Assembly of the European Coal and Steel Community (ECSC), followed by Parliamentary Assembly of the Council of Europe.

In the Parliamentary Assembly, the present-day European Parliament (EP), the represented parties were mainly parties operating at that time in individual states. Due to the manner of electing national representations to the EP, that is, delegating deputies proportionally to the strength of individual political groups in national parliaments, smaller parties or non-attached members had no chance to participate in the work of the EP. What is more, from the very beginning of the EP, it was not national groups that the work of the EP focused on, but transnational factions. This resulted from the fact that an agreement was easier to achieve within the same families of political parties, even despite certain differences in national interests, than between parties from the very same country, yet representing often a thoroughly different vision of economic and social development, as well as different views on the European integration.

It is also important to realise that collaboration of parties from different countries within political groups, which in itself entails the risk and the necessity to continuously align varying interests, is one thing, whereas creating alliances between political groups in a situation where neither faction has a sufficient number of votes to carry out a specific project on its own is yet another challenge. In the first part of this article, general principles for creating political groups in the EU shall be presented, followed by theoretical considerations on 
the construction and the functioning of grand coalitions. Lastly, programmes of major factions will be compared in order to determine the ideological cohesion of the formed grand coalitions.

\section{FORMATION OF POLITICAL GROUPS IN THE EP OF THE SEVENTH TERM}

In terms of the regulatory provisions concerning the internal functioning of individual EU institutions, treaty law is highly laconic. Article 232 of the Treaty on the Functioning of the European Union provides that "the European Parliament shall adopt its Rules of Procedure, acting by a majority of its Members"1. Therefore, the basic information on the principles of forming and operating of political groups, as well as their rights, should be sought in the Rules of Procedure of the European Parliament. Internal regulations of the EP pertaining to factions have changed over the years. This was caused primarily by the number of deputies changing after subsequent enlargements of the EC and the EU. The Rules of Procedure of the Common Assembly of the ECSC with 78 deputies adopted in 1953 provide that formation of a political group required only nine members ${ }^{2}$. For a relatively long period of time, that is, until 1999, a faction was formed by deputies from one country, provided the quantitative criterion was met. For obvious reasons, this principle was not conducive to international collaboration, and hindered creation and the functioning of parties at the European level, which have gained a new status and financial privileges since the Maastricht Treaty. In the sixth term of the EP (2004-2009), the following principle was adopted: "A political group shall comprise Members elected in at least one quarter of the Member States. The minimum number of Members required to form a political group shall be 25" (Rule 29.2 of the Rules of Procedure ${ }^{3}$ ). However, on the basis of the Decision of the European Parliament of 9 July 2008 on amendments to Rule 29 of the Rules of Procedure of the European Parliament, formal requirements were raised and remain effective as of the first day of the first part-session

\footnotetext{
1 The Treaty on the Functioning of the European Union (consolidated edition; OJ EU C 202 of 7 June 2016).

${ }^{2}$ More on the change of rules and the quantitative criterion for creating factions in the EP, see: Kosowska-Gąstoł, 2011, p. 104-107.

3 The Rules of Procedure of the European Parliament, 16th Edition (OJ EU L 44 of 15 February 2005).
} 
following the 2009 European Parliament Elections. Creation of a political group has since required at least twenty-five deputies elected in at least one quarter of member states. This solution was supported by two major political camps in the EP - Christian democrats - the group of the European People's Party (EPP), and the Party of European Socialists (PES). Minor factions were in favour of preserving previous regulations. For instance, Andrew Duff, representative of the Alliance of Liberals and Democrats for Europe (ALDE), argued, "minority opinions have just as much right to be organised professionally as majority opinions", adding that "closing down smaller groups would either force reluctant deputies to join larger groups, adding to their incoherence, or inflate the ranks of the non-attached, adding to inefficiency" ${ }^{4}$. On the other hand, Ilda Figueiredo, representative of the Confederal Group of the European United Left - Nordic Green Left (GUE/NGL), justified opposition of her faction in the following words: "This means it will be more difficult to form small political groups in the European Parliament, which is one more obstacle to the affirmation of positions that differ from those of the dominant ideology in this increasingly neoliberal, militarist and federalist European Union. One final remark on the process followed by the majority groups, the PPE-DE and the PSE Groups. They began by presenting a proposal requiring 30 members to form a political group. They then blackmailed some smaller political groups to gain their support for a so-called compromise proposal, the one that has just been approved"5. Interestingly, despite the official collaboration of Christian democrats and conservatives, forming the joint faction European People's Party - European Democrats (EPP-ED) since 1999, conservatives did not support the stance of their coalition partners. Timothy Kirkhope, their representative in the Committee, presented the following argument for that step: "The balance between the efficient operation of the Parliament and the need to recognise the plurality of voices and opinions within the Parliament must be struck with care. This would be better achieved by retaining the thresholds for the constitution of a political group as they currently are. Although we recognise there is a fair case for increasing the number of Members required to form a group, any increase in the requirement of the

4 Source: Richard Corbett's Draft Report of 2 June 2008 for the Committee on Constitutional Affairs for the EP on Amendment of Rule 29 of Parliament's Rules of Procedure - Formation of Political Groups (2006/2201(REG)), http://www.europarl.europa.eu/sides/getDoc.do?pubRef=-//EP//TEXT+CRE+20080709+ITEM-007+DOC+XML+V0//EN, accessed 31 March 2016.

${ }^{5}$ Ibid. 
number of Member States would unfairly and unnecessarily disadvantage smaller

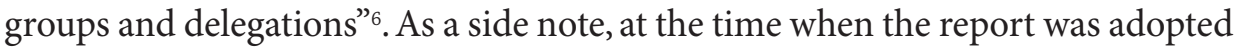
in the Committee, the cooperation of Christian democrats and conservatives was basically losing ground. Due to their ideological differences, conservatives decided to recreate the former collaboration between conservative parties in the EP. Works to this end intensified after David Cameron was elected chairman of the British Conservative Party in 2005. Nevertheless, the separate faction in the EP of the sixth term has not been formed - this took place only after the subsequent elections to the EP, when the group of European Conservatives and Reformists (ECR) was founded. Conservatives were most afraid of not being able to meet the raised criterion of the number of states deputies were supposed to be elected from. Eventually, at the beginning of the seventh term, ECR was joined by members elected in eight states?

Apart from changes concerning quantitative criteria for creating factions in the EP a new solution was adopted, allowing a faction to exist even if it did not reach the required threshold for the number of deputies or if the number of member states deputies were from was insufficient, however, the prerequisite being that such a group has to exist for over a year and that members have to represent at least one-fifth of all member states. Decisions in this respect is taken by the EP President in consultation with the Conference of Presidents, thus, the representation of the already existing factions. A group thus constituted can exist until the end of the term (until next inaugural session). The Rules of Procedure provide that the President may forbid such a faction if he or she considers it abusive. This might occur in the situation where a large faction makes an artificial division in order to gain certain administrational, organisational, or financial privileges.

When considering the principles for creating a coalition between factions in the EP, one ought to mind the ideological cohesion within individual factions. Rule 30.1 of the EP Rules of Procedure of the seventh term ${ }^{8}$ provides

${ }^{6}$ Ibid.

7 Source: Conservative MEPs Form New Group (2009), The Official Website of BBC, http://news. bbc.co.uk/2/hi/uk_news/politics/8112581.stm, accessed 31 March 2016. The document that constitutes cooperation of conservatives at the EU level is the Prague Declaration of 2009. For more information, see: the official website of ECR - http://ecrgroup.eu/, accessed 31 March 2016.

${ }^{8}$ Currently Rule 32.1 of the Rules of Procedure, 8th Parliamentary Term, July 2014, http://www. europarl.europa.eu/sipade/rulesleg8/Rulesleg8.EN.pdf, accessed 25 March 2016. In terms of the functioning of political groups, the Rules of Procedure of the European Parliament of the eight term, in the title I, chapter 4 titled "Political Groups" duplicate the provisions of the Rules of Procedure of 
that "members may form themselves into groups according to their political affinities"9. The Rules of Procedure also contain an interpretation of this provision, according to which, in principle, Parliament does not assess affinities of the members forming a faction unless they negate each other's opinions. The aim of this protective measure is to guarantee that the EP is guarded against formation of technical factions or, to use a more accurate term, 'rainbow factions', composed of non-attached deputies of various policy options. However, it is hard to imagine a situation where the EP decides to dissolve a group due to programme differences or lack of ideological cohesion. That might be interpreted for an attempt to limit pluralism at the EP level. What is more, taking into consideration also Rule 2 of the Rules of Procedure, which states that the free mandate is exercised by MPs and prohibits them from accepting instructions, it seems that the interpretation of Rule 30.1 is only pro forma ${ }^{10}$. Rule 31 of the Rules of Procedure of the EP (currently Rule 33) on activities and legal situation of political groups provides that factions fulfil their functions, including tasks imposed on them by the Rules of Procedure, within the scope of the work conducted by the EU. It also ensures them the access to relevant administrative infrastructure. Political groups are mentioned in the Rules of Procedure of the EP in as many as 56 of the total 216 rules. The significance of political groups is evidenced by the fact that in numerous matters only political groups composed of at least 40 members have the right to make a proposal. This solution shows that in order to mark their presence and to propose their ideas for discussion, non-attached members oftentimes have to establish technical alliances. Alliances of this sort are usually formed ad hoc. It was once common to form the so-called technical factions, also called 'rainbow factions', which reflected the ideological diversity of deputies forming such groups (Kosowska-Gąstoł, 2011, p. 110-114).

Moreover, the Rules of Procedure pertain to the collaboration between political groups. Rule 32 (currently Rule 34 ) discusses the possibility to create intergroups by members with the aim to contribute to an exchange of opinions

the European Parliament of the seventh term, the only element amended being the numbering of individual rules.

9 The Rules of Procedure of the European Parliament of the Seventh Term, March 2011 (OJ EU L 116 of 5 May 2011).

10 At present, one could hardly consider that the members exercise free mandate, as the contemporary democracy is based on political parties, which decide who will fill vacancies on tickets, and even in the context of majority systems non-attached candidates are rare and stand little chance of securing an office. As early as in the interwar period, Hans Kelsen postulated that the MPs mandates should be imperative - a party mandate (1936, chapter I). 
on specific issues between different political groups, thus bringing together members of different committees. Whereas in Rule 19, which considers the possibility to remove, e.g., the president or vice-presidents of the EP from their duties before the end of the term, it is provided that such a request can be submitted by the Conference of Presidents acting by a three fifths majority of the votes cast representing at least three political groups. In this context, one ought to note that the Conference of Presidents itself is a specific internal body of the EP, where political groups have an exceptionally strong position. The Conference consists of the President of the EP and chairmen of political groups. Non-attached deputies have one representative who is not entitled to vote (Rule 24; currently Rule 26). The Conference takes decisions on, i.a., the organisation of parliamentary work and matters related to planning of legislative work (Rule 25.2; currently Rule 27.2) with its usual goal being to reach a consensus, though if agreement is not possible, voting takes place, in which the votes cast are subject to a weighting based on the number of members in each political group (Rule 24.3; currently Rule 26.3). In this situation, non-attached deputies are deprived of any influence whatsoever, whereas works of the EP are decided on by coalitions of political groups ${ }^{11}$.

Thus, in spite of the fact that political groups are not mentioned in the Treaties at all, they prove to be of key importance in the organisation of works of the EP. Considering the permanently growing significance of this institution in the law-making process and the expansion of the EU legislation itself, as well as its effect on individual member states, it is worth to take a closer look on the rules of cooperation between political groups in the EP.

\section{GRAND COALITIONS - THEORETICAL CONSIDERATIONS}

Considerations pertaining to grand coalitions in the European Parliament ought to be started with stressing the importance of discussing "grand coalitions of coalitions" at the very beginning. As mentioned above, pursuant to the Rules of Procedure of the EP, formation of a political group requires a representation of

11 For more information on the legal status of political groups in the EP and the evolution of their positions, see: Gagatek (2007, p. 83-111). In his article, the author analyses the contents of the Rules of Procedure of the EP and makes a reference to the case law of the Court of First Instance on the interpretation of the regulation concerning the similarity of political opinions. An interesting part of the text is the discussion on the system of financing political groups. 
at least 25 deputies from at least one quarter of all member states. This fact alone makes collaboration between members representing at least seven political parties obligatory within a single faction, hence, the term 'coalition' is most appropriate at this early stage. Considering the political diversity of the EU member states, this sort of coalitions oftentimes is quite loose due to ideological differences between individual groups arising from diverse historical backgrounds or other interests at the EU level. An analysis of votes in the seventh term of the EU shows a relatively high level of cohesion among political groups. The highest level of cohesion was found in the Greens/European Free Alliance (Greens/EFA) $94.68 \%$, followed by EPP $-92.63 \%$. The lowest level of cohesion was exhibited by the Europe of Freedom and Democracy (EFD) - only $48.59 \%{ }^{12}$. National parties often decide to join a given faction not for ideological reasons but for pragmatic reasons, or bring their national political leaning or animosity to the EP level. 'Pragmatism' can be exemplified by the Hungarian Fidesz, which decided to join the largest faction - EPP, while the programme of this party, especially over the last years, has become very conservative and closer to the faction ECR in terms of ideology. Whereas bringing national cooperation to the European level can be exemplified by the coalition between PO and PSL, in which the deputies of both parties belong to EPP. PiS might serve as a negative example, as since 2004 it has been avoiding collaboration in the group of Christian democratic parties (EPP), though it declares the very same programme. Nevertheless, due to national-level issues, i.e., a dispute with PO, in the seventh and the eighth term deputies of this party joined ECR dominated by British conservatives, whose main postulate is to reduce the financing of cohesion policy or the common agricultural policy - with Poland as its main beneficiary. Considerations pertaining to coalitions within political groups are not subject of this research paper, though.

Elections to the EP held basing on national electoral systems are treated by voters as secondary elections with no direct effect on national policy. This approach results in, first of all, a lower turnout in the elections to the EP compared to national parliamentary elections and, second of all, the voters often giving their votes less rationally, i.e., voting on radical or new parties emerging on the political scene, taking the view that they would not challenge the national status $q u o$ and that they are showing the ruling elites and mainstream parties a 'yellow

12 Data based on: European Political Groups Cohesion Rates on All Policy Areas (14.07.200917.04.2014), The Official Website of VoteWatch Europe, http://term7.votewatch.eu/en/political-group-cohesion.html, accessed 31 March 2016. 
card. This makes support of voters disperse and results in major national parties usually recording worse results than in the national parliamentary elections. This, in turn, has an obvious impact at the EP level. First of all, it makes some parties entering to the EP struggle to fit into the existing political configuration in terms of ideology, which makes their deputies often remain non-attached or form quite eclectic factions and, second of all, prevents each of these large political groups from obtaining an absolute majority of votes.

The current research in politics is focused primarily on parties and party systems at national level. Coalition theories refer most of all to this level of interaction between political parties, as well. In general, there are two main schools in coalition studies, namely, quantitative coalition studies, which are based on game theory and developed primarily by American centres, and the European school, which apart from the quantitative factor accounts for the ideological aspect as well. The term 'grand coalition' is most often applied in the context of the German or the Austrian party systems to describe the collaboration between Christian democrats and social democrats. According to the simplest definition of a grand coalition that might be encountered in works dedicated to parties, it is a collaboration between two parties that obtained most votes in elections (Strohmeier, 2009, p. 8). This definition is highly vague, as it points out only to one factor - the election result. Most of all, it does not account for the mechanics of party systems, i.e., positioning of parties on the left-right axis, which is vital for describing the phenomenon of grand coalitions. Moreover, one should also note differences between the grand coalition phenomenon and other types of coalition with a similar yet varying character. In political party theory, the most commonly mentioned coalitions are: minority coalition, majority coalition (and numerous variants of the latter), as well as national unity/national front coalition (government). Minority coalitions occur when the political parties that form them do not have an absolute majority of votes in the parliament. Usually, these are built in times of political crises and constitute the base for a technical government. Scandinavian countries (Norway, Sweden, Denmark) are exception here due to the relatively common minority governments, which are not regarded as a manifestation of a political crisis but an adopted standard. This results from the nature of democracy in the said countries, referred to as consensus democracy, in which the conflict between the ruling party and the opposition is not total and both sides are willing to cooperate and develop a common stance on the most important issues of internal and foreign policy. This is a result of political and constitutional changes that delegate numerous powers to the opposition, such as chairing important parliamentary committees (Strøm, 
1990, p. 25). In the national-level analysis of party systems and political systems, also one-party majority cabinets and one-party minority cabinets are mentioned (Sokół, 2005, p. 178).

Different variants of majority coalitions based on the quantitative criterion constitute a far more interesting object. With their theoretical basis being game theory, they are modelled on a minimal winning coalition. This model is based on arithmetic - an optimal coalition is a coalition composed of a minimum number of parties that gives an absolute majority of votes in the parliament. This concept is based on the assumption that as rational participants of the political process parties seek to maximise their profits - the profit being the possibility to fill public positions. Hence, the smaller the number of parties, the more favourable the situation, as offices are allocated among a smaller number of entities. This variant is sometimes called a minimal size coalition. A specific type of minimal winning coalition is a bargaining coalition, where the strongest party chooses its coalition partner (assuming that there is more than one party that meets the criterion for coalition formation) based on smaller demands. The partially overlapping quality (ideological) criterion and the quantity criterion within the framework of game theory created a minimal rage coalition model, according to which a coalition is formed by the minimum number of parties that gives a majority of votes in the parliament, based on the assumption that coalition partners are divided by the smallest ideological distance, though this does not mean that they have to be in adjacent positions on the left-right axis. This requirement appears in the minimal connected winning coalition model (Kiełmiński, 1992, p. 12-20; Lijphart, 1984, p. 47-50).

In the European context, coalition models based on game theory in the pure form were not appreciated, among others, due to the fact that they treat minority coalitions as a derogation from the standard, whereas empirical studies show that cabinets of this sort (including one-party minority cabinets) make up for over one-third of the total number in Europe (Sobolewska-Myślik, 2004, p. 146). Only when complemented with the analysis of the rich experience of forming coalitions on the continent could these models be employed in a subsidiary way. The most vital element that one ought to have in mind is the fact that parties are not static entities, as they are ever evolving in terms of programme and organisation, which affects how they perceive the environment (including other parties) and how they are perceived by this environment. What is more, coalitions are not always formalised and can be established ad hoc, which complicates the analysis of the grand coalition phenomenon even further. 
When considering the principles for forming coalitions at the EP level, the legal and constitutional character of the European Union itself is not without significance. The transposition of concepts and patterns used for describing and explaining phenomena that take place at the national level is not always justified in the case of the EU, which, regardless of its certain quasi-national traits, remains an international organisation. Until quite recently, the category of the EU political system spurred concern. Nevertheless, the existence of this system at the EU level might be recognised, yet characterised by numerous specific traits $^{13}$. The main research problem in the view of the discussed subject is the determination of the position of the European Commission (EC) and its political responsibility. The procedure for appointing the $\mathrm{EC}$ requires the involvement of the EP, the European Council (EC), and member states. Still, the Commission itself is not a homogeneous institution in the political sense but another grand coalition composed of politicians designated by individual states. The European Parliament takes active part in the procedure of establishing the Commission, while the Treaty of Lisbon put additional emphasis on the meaning of elections to the EP, indicating that the European Council should take into account results of the previous elections to the EP (Article 17.7 of the Treaty on the European Union $^{14}$ ), which means that a candidate for the President of the European Commission ought to come from the political environment of the victorious factions (or should be supported by that faction, e.g., in a situation where it establishes coalition with other political group). By approving the members of the Commission, the EP gives a vote of confidence to the grand coalition, which does not necessarily have to reflect the political image of the EP and correspond to the current coalition in the EP. Hence, it is difficult to consider the relations between the Parliament and the Commission a reflection of the relations that link parliaments with governments on the national level. The European Parliament does not guarantee stability and sustainability of the European Commission, and a shift in the balance of power in the Parliament by means of creating new coalitions in general does not affect the European Commission. Thus, political groups in the EP must be affected by some other consolidation factor.

13 The traits of the political system of the European Union are depicted in detail by Simon Hix. He defines this category by means of, i.a., the cybernetic model of David Easton's political model. See: Hix (2010, p. 28-32).

14 The Treaty of the European Union (consolidated edition; OJ EU C 202 of 7 June 2016). 
When writing about formation of coalitions in the EP, Simon Hix notes that "there is no permanent coalition in the European Parliament, and without a government to support, legislative coalitions are formed vote by vote. On many issues the European Parliament behaves as if it were a single actor seeking to promote its own powers and interests against the interests of the second legislative chamber in the EU (the Council) or against the holders of executive power (the Commission)" (Hix, Hoyland, 2011, p. 59). The pragmatics of political groups make coalitions that in many cases would stand no chance to be implemented on the national level common in the EP. The scope of a coalition and its membership often depend on the discussed problem subjected to voting. Therefore, these coalitions can be formed basing on an ideological criterion - in cases pertaining to civil rights and liberties - here, collaboration of social democrats and the greens or social democrats and liberals is most common; economy and monetary policy, where on one side there are Christian democrats with liberals and social democrats with the greens on the other; coalitions on matters related to natural environment and public health are formed by Christian democrats and conservatives, and on the opposite side - by social democrats and the greens or the European United Left - Nordic Green Left (GUE/NGL); on matters concerning industry, research and energy, coalitions are most often established between Christian democrats and conservatives or social democrats and liberals ${ }^{15}$. The above summary shows the mechanism of a minimal connected winning coalition. The alliances formed pertain to groups that are adjacent on the left-right axis. It should be noted, however, that due to the eclectic nature of political groups, their situation on the left-right dimension is hindered. One should also have in mind that the position of liberal parties often becomes shifted. Most often, they are positioned in the centre between social democrats and Christian democrats (in the case of social-liberal parties), yet if liberal parties have a more right-wing character, then their position shifts and they will be situated between Christian democrats and conservatives. Basing on the allocation of seats in the chamber of the EP it might be assumed that the left-right axis in the EP of the seventh term was as follows: the Europe of Freedom and Democracy (EFD) - the European Conservatives and Reformists (ECR) - the European People's

15 Source: The Activity Records of MEPs Analysed by EP Group and National Party. End-of-term Scorecard, Part 2, VoteWatch Europe Special Policy Brief 3/2014, http://www.votewatch.eu/blog/ wp-content/uploads/2014/05/votewatch-europe-end-of-term-scorecard-part-2-groups-final.pdf, p. 10, accessed 31 March 2016. 
Party (EPP) - the Alliance of Liberals and Democrats for Europe (ALDE) - the Greens/European Free Alliance (Greens/FEA) - the Group of the Progressive Alliance of Socialists and Democrats in the European Parliament (S\&D) - the European United Left - Nordic Green Left (GUE/NGL) ${ }^{16}$. Nevertheless, a more commonly applied solution is building grand coalitions independently of the ideological criterion. Usually, in matters of agricultural policy, constitutional or institutional affairs, as well as in legal matters, rand coalitions are established between Christian democrats and social democrats ${ }^{17}$. Here, the role of ALDE can be additionally noted, providing support to EPP and S\&D in this voting. The participation of liberals, who are situated on the left on the left-right axis directly next to the Christian democrats, shortens the distance between EPP and social democrats. This situation may represent a 'grand grand coalition'. Still, what determines the establishment of cooperation between Christian democrats and social democrats despite obvious programme differences and ideological distance? Hix, who was quoted above, claims that the crucial role is played here by decision-making procedures in the EP. In the case where an absolute majority of votes is required for a decision to be taken, a coalition composed of several partners is uneconomical and oftentimes impossible due to tenders, in which each group strives to obtain specific advantages. In such case, the best solution is an alliance formed by two largest groups. Hix additionally explains the collaboration between Christian democrats, socialists and liberals by the pro-European character of these groups, in contrast to others which are more or less Eurosceptic (2010, p. 133).

\section{SUMMARY}

The European integration of the $2010^{\text {s }}$ bears a slight resemblance to the process initiated in the 1950s. The membership of the organisation was considerably expanded. Each consecutive enlargement of Communities/the Union affected the scope and the level of integration and raised new problems and challenges. One of the attempts made by the Union itself to answer the transforming internal situation and new international challenges was to expand the competencies of

16 Own work based on the official webpage of the European Parliament, http://www.europarl. europa.eu, accessed 31 March 2016.

17 Source: The Activity Records of MEPs..., p. 10. 
the European Parliament, which is the only institution to be democratically legitimised directly from the citizens.

Being aware of its specific role in the institutional system and the entire European integration process, the European Parliament strives to develop (also by means of internal regulations concerning organisation of its work) an operating model that would satisfy as best as possible both political and social expectations concerning the Parliament.

One of the characteristic traits of works in the European Parliament is the concentration of majority of rights on the part of political groups. The very fact that European Parliament deputies, elected basing on national electoral systems, associate in political groups instead of national groups is a worldwide phenomenon. This provides an undeniable evidence of the success of integration, in which national interests and animosities were managed to be overcome in favour of cooperation focused on ideological and political issues.

Internal regulations of the European Parliament regarding the formation and the functioning of political groups put the emphasis on their greatest possible diversification in terms of nationality, yet at the very same time they introduce a quality criterion, i.e., convergence of political opinions. Thus, by means of formal regulations, the cooperation of parties from different countries becomes a necessity. Nonetheless, at the current stage of integration, it seems that collaboration within individual families of political parties would take place in either situation. Beyond doubt, these regulations aim at forming a pan-European party system, in which this process could be crowned with elections based on one electoral system binding for the entire European Union, where national parties would give up their national names and participate in elections on common European party electoral lists.

A distinct question of great importance in the view of the functioning of both the European Parliament and the EU itself as an international organisation with transnational elements is the formation of a coalition between political groups. Empirical studies and analyses of the EP voting prove that permanent coalitions at the EP level are non-existent. The most common situation is an agreement between two major political groups - Christian democrats (EPP) and social democrats (S\&D), yet also other coalitions are possible, including a coalition between Christian democrats (EPP), social democrats (S\&D) and liberals (ALDE). The first situation can be called a grand coalition, whereas the second case is a 'grand grand coalition'. While on the national level such situations are rare and occur most frequently when no major party gains an absolute majority of 
votes and, additionally, has no possibility to obtain coalition partners from among smaller parties, both types of grand coalitions are standard in the EP and have become a characteristic element of this institution. This is a double-edged sword. One of the advantages is undoubtedly the creation of broad support for specific compromise solutions, whereas one of the disadvantages is blurred programme differences between individual political groups, which might be incomprehensible for the electorate and may lead voters to consequently give their vote in the subsequent election to a party with a more distinct ideological image.

In conclusion, the traditional conceptual framework used in politics for describing a political system fails when it comes to defining the political system of the European Union. Not all terms are applied or are applicable and they not always stand for the same phenomenon both on the national and the EU level. The attempt to typologize the EU party system basing on the functioning of political groups in the EP escapes the classic definition, which does not mean, however, that such attempts should be discontinued.

\section{REFERENCES:}

Conservative MEPs Form New Group (2009). The Official Website of BBC. Retrieved from: http://news.bbc.co.uk/2/hi/uk_news/politics/8112581.stm, [accessed 31.03.2016].

Duff, A. (2008). Richard Corbett's Draft Report of 2 June 2008 for the Committee on Constitutional Affairs for the EP on Amendment of Rule 29 of Parliament's Rules of Procedure - Formation of Political Groups (2006/2201(REG)). Retrieved from: http://www. europarl.europa.eu/sides/getDoc.do?pubRef=-//EP//TEXT+CRE+20080709+ITEM007+DOC+XML+V0//EN, [accessed 31.03.2016].

European Political Groups Cohesion Rates on all Policy Areas (14.07.2009-17.04.2014). The Official Website of VoteWatch Europe. Retrieved from: http://term7.votewatch. eu/en/political-group-cohesion.html, [accessed 31.03.2016].

Figueiredo, I. (2008). Richard Corbett's Draft Report of 2 June 2008 for the Committee on Constitutional Affairs for the EP on Amendment of Rule 29 of Parliament's Rules of Procedure - Formation of Political Groups (2006/2201(REG)). Retrieved from: http://www. europarl.europa.eu/sides/getDoc.do?pubRef=-//EP//TEXT+CRE+20080709+ITEM007+DOC+XML+V0//EN, [accessed 31.03.2016].

Gagatek, W. (2007). Status prawny frakcji politycznych w Parlamencie Europejskim. Studia Europejskie, 2, 83-111.

Hix, S. (2010). System polityczny Unii Europejskiej. Warszawa: PWN.

Hix, S., Hoyland, B. (2011). The Political System of the European Union (3 ${ }^{\text {rd }}$ ed.). New York: Palgrave Macmillan.

Kelsen, H. (1936). O istocie i wartości demokracji. Warszawa: Księgarnia Powszechna. 
Kiełmiński, Z. (1992). Teorie zwycięskich koalicji w demokracji parlamentarnej (zarys problematyki). In: Z. Kiełmiński, T. Mołdawa (eds.), Parlament $w$ demokracjach zachodnich (p. 12-20). Warszawa: Elipsa.

Kirkhope, T. (2008). Richard Corbett's Draft Report of 2 June 2008 for the Committee on Constitutional Affairs for the EP on Amendment of Rule 29 of Parliament's Rules of Procedure - Formation of Political Groups (2006/2201(REG)). Retrieved from: http://www. europarl.europa.eu/sides/getDoc.do?pubRef=-//EP//TEXT+CRE+20080709+ITEM007+DOC+XML+V0//EN, [accessed 31.03.2016].

Kosowska-Gąstoł, B. (2011). Zasady tworzenia grup politycznych w Parlamencie Europejskim ze szczególnym uwzględnieniem tzw. frakcji technicznych. Przegląd Sejmowy, 6, 99-116.

Lijphart, A. (1984). Democracies. Patterns of Majoritarian and Consensus Government in Twenty-One Countries. New Haven-London: Yale University Press.

Richard Corbett's Draft Report of 2 June 2008 for the Committee on Constitutional Affairs for the EP on Amendment of Rule 29 of Parliament's Rules of Procedure Formation of Political Groups (2006/2201(REG)). Retrieved from: http://www. europarl.europa.eu/sides/getDoc.do?pubRef=-//EP//TEXT+CRE+20080709+ITEM007+DOC+XML+V0//EN, [accessed 31.03.2016].

Sobolewska-Myślik, K. (2004). Partie i systemy partyjne na świecie. Warszawa: PWN.

Sokół, W. (2005). Partie polityczne na arenie wyborczej i gabinetowej. In: W. Sokół, M. Żmigrodzki (eds.), Współczesne partie i systemy partyjne. Zagadnienia teorii i praktyki politycznej (p. 158-189). Lublin: Wyd. UMCS.

Strohmeier, G. (2009). Große Koalitionen in Deutschland und Österreich. Zeitschrift für Politikwissenschaft, 1, 5-37.

Strøm, K. (1990). Minority Government and Majority Rule. Cambridge: Cambridge University Press.

The Activity Records of MEPs Analysed by EP Group and National Party. End-of-term Scorecard, Part 2 (2014). VoteWatch Europe Special Policy Brief 3/2014. Retrieved from: http://www.votewatch.eu/blog/wp-content/uploads/2014/05/votewatcheurope-end-of-term-scorecard-part-2-groups-final.pdf, [accessed 31.03.2016].

The Official Webpage of the European Parliament. Retrieved from: http://www.europarl. europa.eu, [accessed 31.03.2016].

The Prague Declaration of 2009. The Official Website of ECR. Retrieved from: http:// ecrgroup.eu/, [accessed 31.03.2016].

The Rules of Procedure, $8^{\text {th }}$ Parliamentary Term, July 2014. Retrieved from: http://www. europarl.europa.eu/sipade/rulesleg8/Rulesleg8.EN.pdf, [accessed 25.03.2016].

The Rules of Procedure of the European Parliament, 16 ${ }^{\text {th }}$ Edition (OJ EU L 44 of 15 February 2005).

The Rules of Procedure of the European Parliament of the Seventh Term, March 2011 (OJ EU L 116 of 5 May 2011).

The Treaty of the European Union (consolidated edition; OJ EU C 202 of 7 June 2016).

The Treaty on the Functioning of the European Union (consolidated edition; OJ EU C 202 of 7 June 2016). 